\title{
Geophysical Data Processing for the Delineation of Tectonic Lineaments in South Cameroon
}

\author{
Quentin Marc Anaba Fotze ${ }^{1,2}$, Charles Antoine Basseka ${ }^{3}$, Anatole Eugene Djieto Lordon ${ }^{1}$, Albert Eyike Yomba ${ }^{4}$, \\ Yves Shandini ${ }^{5} \&$ Jean Marie Tadjou ${ }^{5,6}$ \\ ${ }^{1}$ Department of Geology, University of Buea, Faculty of Science, Buea, Cameroon \\ ${ }^{2}$ Centre for Geological and Mining Research, Garoua, Cameroon \\ ${ }^{3}$ Department of Earth Sciences, Faculty of Science, University of Douala, Cameroon \\ ${ }^{4}$ Department of Physics, Faculty of Science, University of Douala, Cameroon \\ ${ }^{5}$ Department of Physics, Faculty of Science, University of Yaounde I, Cameroon \\ ${ }^{6}$ National Institute of Cartography (NIC), Yaounde, Cameroon \\ Correspondence: Anatole Eugene Djieto Lordon, Department of Geology, Faculty of Science, University of Buea, \\ Cameroon. Tel: 237-699-392-491. E-mail: djietolordon@gmail.com
}

\author{
Received: February 8, $2019 \quad$ Accepted: February 28, $2019 \quad$ Online Published: March 25, 2019 \\ doi:10.5539/esr.v8n2p1 URL: https://doi.org/10.5539/esr.v8n2p1
}

\begin{abstract}
The processing of aeromagnetic and gravity data of the Northern part of Congo Craton (South Cameroon region), between latitudes $2^{\circ} 30^{\prime}-3^{\circ} 30^{\prime} \mathrm{N}$ and longitudes $12^{\circ}-13^{\circ} \mathrm{E}$, permitted the determination of the structural features ccurring within the Precambrian basement (Ntem Complex) southwards and the Pan-African belt (Yaounde Group) northwards. The maxima of the Horizontal Gradient within the study area, were obtained using the Blakely and Simpson method (1986). Those maxima were used to trace the magnetic lineaments of the study area. Furthermore, the Total Horizontal derivative of the Tilt derivative applied on the residual grid of Bouguer anomaly guaranteed the enhancement of linear structures which were automatically extracted using the CET Grid Analysis algorithm. The superimposition of both magnetic and gravity lineaments allowed us to display the structural framework of the area, whose major trending directions are E-W, ENE-WSW, and NE-SW. These major lineament directions are likely to be linked to one or more than a single tectonic event such as the ENE-WSW/NE-SW trends, considered as the subduction direction of the Congo craton beneath the Pan-African belt. These trends may be linked to the Eburnean orogeny and are also said to be connected to the Central African Shear Zone (CASZ). The geophysical lineaments identified in the study are defined as potential targets along which mineralization may have been formed, considering the economic potential of the area.
\end{abstract}

Keywords: Ntem Complex, Pan-African fold belt, aeromagnetic data, gravity data, horizontal gradient, total horizontal derivative of the tilt derivative

\section{Introduction}

The study area is located in the South region of Cameroon, at the transition zone between the Congo craton and the Pan-African mobile belt. The area was subjected to a major tectonic event, i.e. the collision between the stable cratonic area and the mobile belt (Toteu et al., 2004; Shandini et al., 2011; Basseka et al., 2011; Feumoe et al., 2012; Ndougsa-Mbarga et al., 2012). This collision led to the southward thrusting of the Pan-African mobile belt onto the Congo craton of aout 50 to $150 \mathrm{~km}$ (Shandini et al., 2011; Basseka et al., 2011; Feumoe et al., 2012; Ndougsa-Mbarga et al., 2012). As a result, a part of the Archean basement is concealed beneath the Pan-African units, making direct geological studies of the Congo craton basement difficult to achieve; besides, the dense vegetal coverage characterizing the area highly represents an obstacle for field geological studies; hence the necessity of using airborne geophysical surveys .

Previous geophysical studies, have been carried out in the South region in order to delineate the tectonic lineaments. Indeed, Tadjou et al., (2009), Shandini et al., (2010), and Basseka et al., (2011), used gravity data to extract the subsurface structures along the northern edge of the Congo craton; those studies emphasized on the Spectral Analysis and 2D1/2 modeling. Besides, Feumoe et al., (2012) used the maxima of the First Vertical 
Derivative to map lineaments in the south-eastern area via magnetic data; in the same area, Ndougsa-Mbarga et al., (2012) combined the Analytic Signal, Horizontal Gradient and Euler Deconvolution methods to illustrate and provide the depths of the magnetic structures. Basseka et al., (2016) used EMAG2 data to map subsurface structures at a regional scale; this was achieved by the superimposition of Analytic Signal and Tilt Derivative maxima. Likewise, Yandjimain et al., (2018) used the Tilt Derivative and Euler Deconvolution methods to trace magnetic structures and provide their depths; the structures obtained from that study were interpreted as vertical contacts.

However, the subsurface structures of the basement is still an issue and the real challenge in this regard is that the underlying subsurface structures of the western part of South Cameroon (study area) are currently not understood. Furthermore, major iron ore deposits have been discovered in the study area at Djoum-Nkout localities by Afferro Mining exploration companies (check www.afferro-mining.com for details), and exploration is still going on.

Thus, by considering all the issues mentioned above, this study aims at providing a well detailed structural map of the area, illustrating hidden structures which may be observed as potential targets for prospective mineral explorations. This will be achieved based on the processing of both magnetic and gravity data.

\section{Geologic and Tectonic Setting}

The study area encompasses $12321 \mathrm{~km} 2$ and is made up of two geotectonic units: the Neoproterozoic mobile belt represented by the Yaoundé Domain (YD) in the northern part and the Archean formation of the Congo craton called the Ntem Complex (NC) in its southern part (Figure 1).

The NC represents the northwestern part of the Congo craton and is well exposed in South Cameroon (Maurizot et al., 1986). It is bordered to the north by the Yaoundé Domain. The NC is subdivided into three units: Nyong, Ayna, and Ntem which represents the southern geology of our study area.

The Ntem unit is dominated by younger intrusive complexes, banded series and greenstone belts. Intrusive complexes are primarily constituted of TTG (Tonalite-Trondjemite-Granodiorite) suite and magmatic charnockitic suite (Pouclet et al., 2007). The TTG unit is characterized by three rock types: the tonalitic suite (commonly called "So'o granite"), the trondjemite suite, and the granodioritic suite (Shang et al., 2004). The tonalitic suite is mostly occurring to the north, along fault boundary with formations of the Yaoundé Domain (Shandini et al., 2011).

The banded series is illustrated by strongly deformed granulitic gneisses (leptynites, granitic gneisses, enderbergites, and charnockitic gneisses) that are spread over the southern part of the Ntem unit (Takam et al., 2009).

In the Ntem unit, greenstones are found as both dismembered belts cross-cut by late syenitic plutons and doleritic veins (Tchameni et al., 2001) and as xenoliths in the intrusive series indicating an older age (Shang et al. 2007). These rocks consist of Banded iron formations (BIFs), metagraywackes, pyroxenites, garnet-bearing amphibolites and sillimanite-bearing paragneisses (Tchameni et al., 2010). Iron ores associated with BIFs (Nforba et al., 2010) constitute one of the economic lithologies of the NC. According to Tchameni et al., (2001), greenstones were affected by granulite-facies metamorphism with P-T conditions reaching $750 \pm 50{ }^{\circ} \mathrm{C}$ at $5-6$ kbar. Besides, Tchameni et al., (2004) used the $\mathrm{Pb}-\mathrm{Pb}$ zircon evaporation technique to date the emplacement of greenstone belts in the Ntem unit at ca. 3.1 Ga.

Two major periods of deformation affected The NC. The first includes successive diapiric emplacements of the TTGs and Mesoarchean charnockites. This event is characterized by stretching and isoclinal folds, vertical lineation and foliation (Shang et al., 2004). This period of deformation occurred at the same time with a regional granulite-facies metamorphism (Tchameni, 1997). In the Paleoproterozoic, this first episode of deformation was followed by a transcurrent deformation phase illustrated by the occurrence of N-S to NE-SW trending sinistral shear zones and partial melting of the greenstone belt rocks and the TTG suite, followed by the generation of granites (Shang et al., 2007). During this second tectonic event, late syenitic plutons $(\sim 2.3 \mathrm{Ga})$ intruded the NC (Tchameni et al., 2001). According to Toteu et al., (1994), the Eburnean metamorphism, dated at $\sim 2.05 \mathrm{Ga}$, affected all the Archean and Paleoproterozoic rocks. 

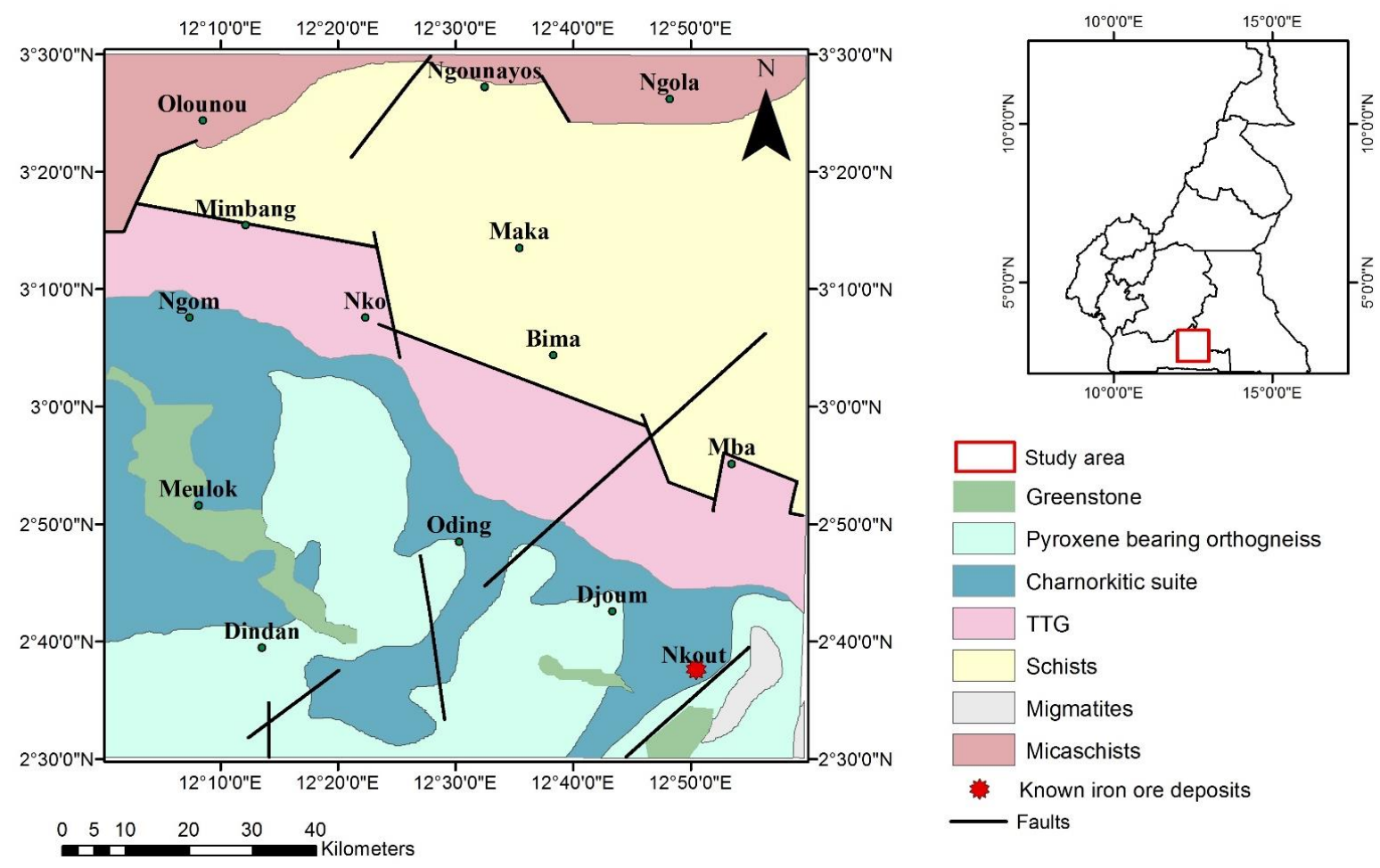

Figure 1. Geological map of the study area (modified after Maurizot et al. 1986)

The Yaounde domain (YD) is the southernmost part of the Oubanguide complex (Poidevin 1983; Ngako et al., 2003; Owona et al., 2012) which is the southern part of the Central African Fold Belt (CAFB) formed during the collision of Congo, West African and East Sahara cratons during the Pan-African orogeny ( 600 Ma; e.g., Abdelsalam et al., 2002; Ngako et al., 2003; Owona et al., 2012). This domain is interpreted as an allochtonous nappe thrusted onto the autochtonous Congo craton (Ntem Complex). The YD is made up of low-to high-grade garnet-bearing schist, orthogneisses and gneisses which had been subjected to medium-high pressure metamorphism reaching the granulite facies (Toteu et al., 2004). In the study area, the YD consists of the Mbalmayo-Bengbis series and the Yaoundé series known as "intermediate series". The Mbalmayo-Bengbis series are dominated by schist and quartzites which recrystallized in the greenschist facies conditions (Vicat et al., 1998). The Yaoundé series consists of strongly deformed metamorphic rocks (schists and gneisses) and migmatites (Nzenti et al., 1988). Sm-Nd isotopic data from Toteu et al., (1994) and Toteu et al., (2001) indicate that the metaigneous and metasedimentary rocks originated from a protolith made up of a mixture of juvenile Paleoproterozoic and Neoproterozoic sources without noticeable contribution from the Congo craton. The only possible source for old components is illustrated by the Paleoproterozoic basement of north-central Cameroon, which suggests that the Yaoundé series were fomed in the internal zone of the mobile belt before the southward thrusting onto the Congo craton (Toteu et al., 2004).

The structural framework of the study area is marked by the subduction of the Congo craton under the Pan-African belt. This implies an extension of the Congo craton beneath the Pan-African units. Hence, this subduction event suggests that deep structures may have been formed as a result of the collision between the Pan-African and the Archean units.

\section{Materials and Methods}

\subsection{Materials}

\subsubsection{Aeromagnetic Data}

The aeromagnetic data used in this study were acquired during the airborne magnetic survey of the South Cameroon and surrounding areas, carried out by the companies CGG (Compagnie Générale de Géophysique; 1962) and SURVAIR (1970). Aeromagnetic surveys were collected along 50 flight lines, with a nominal flight line spacing of 750-1000 m at a flight height varying from 200 to $235 \mathrm{~m}$. Later on, Corrections were applied to the data considering the temporal variations of the magnetic field and the subtraction of IRGF (International 
Reference Geomagnetic field). Geosoft software V 8.4 was used in order to apply the different algorithms required for the processing of the aeromagnetic data. The corrections mentioned above allowed us to obtain the total magnetic intensity (TMI) anomaly data. Before being merged into a unified digital grid with a cell size of $1.1 \mathrm{~km}$, the TMI anomaly data were upward continued to $1 \mathrm{~km}$ to reduce high-frequency noise in the data. This grid of values allowed us to obtain the TMI anomaly map of the area (Figure 2a).

However, the sources of anomalies cannot be precisely discriminated using the TMI anomaly map. Indeed, due to the dipolar nature of the magnetic field, we performed an RTE (Reduction-to-the Equator) of the TMI (Figure 2b). Moreover, in magnetic equatorial areas where the inclination is less than $15^{\circ}$, such as in our study area, RTP (Reduction-to-the Pole) is commonly unstable and could not be derived. Reduction-to-the Equator (RTE) instead of to the pole gives better results in this way. Indeed, once the magnetic field has been reduced to the equator, the regional field will be horizontal as well as most of the source magnetizations. This operator enhances the location and the shape of the anomalies allowing a correlation with the causative sources. The reduction-to-the-equator was performed using Geosoft software 8.4 (transformation done in the Fourier domain) with an inclination of -18.59 and a declination of -6.13 .

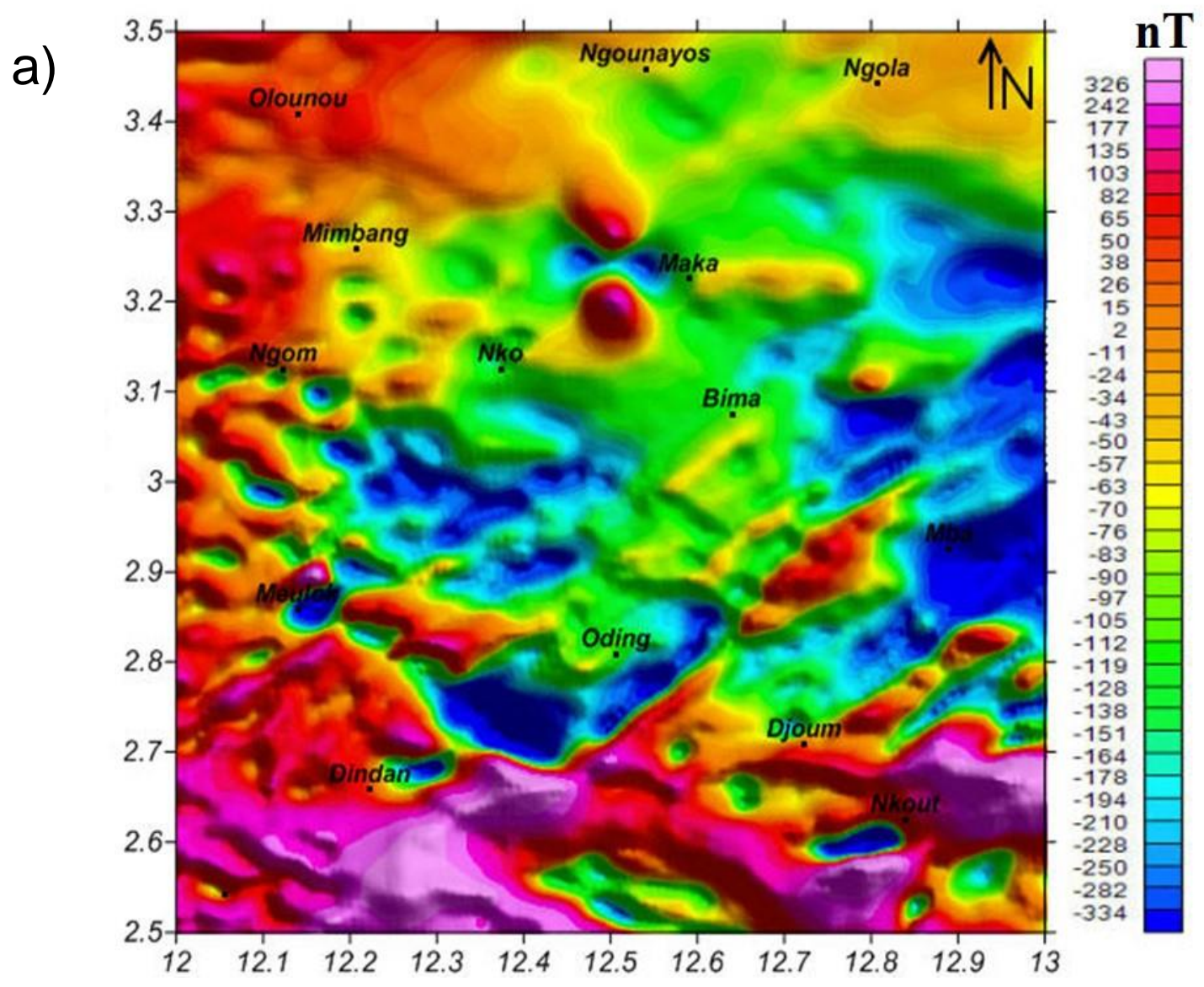




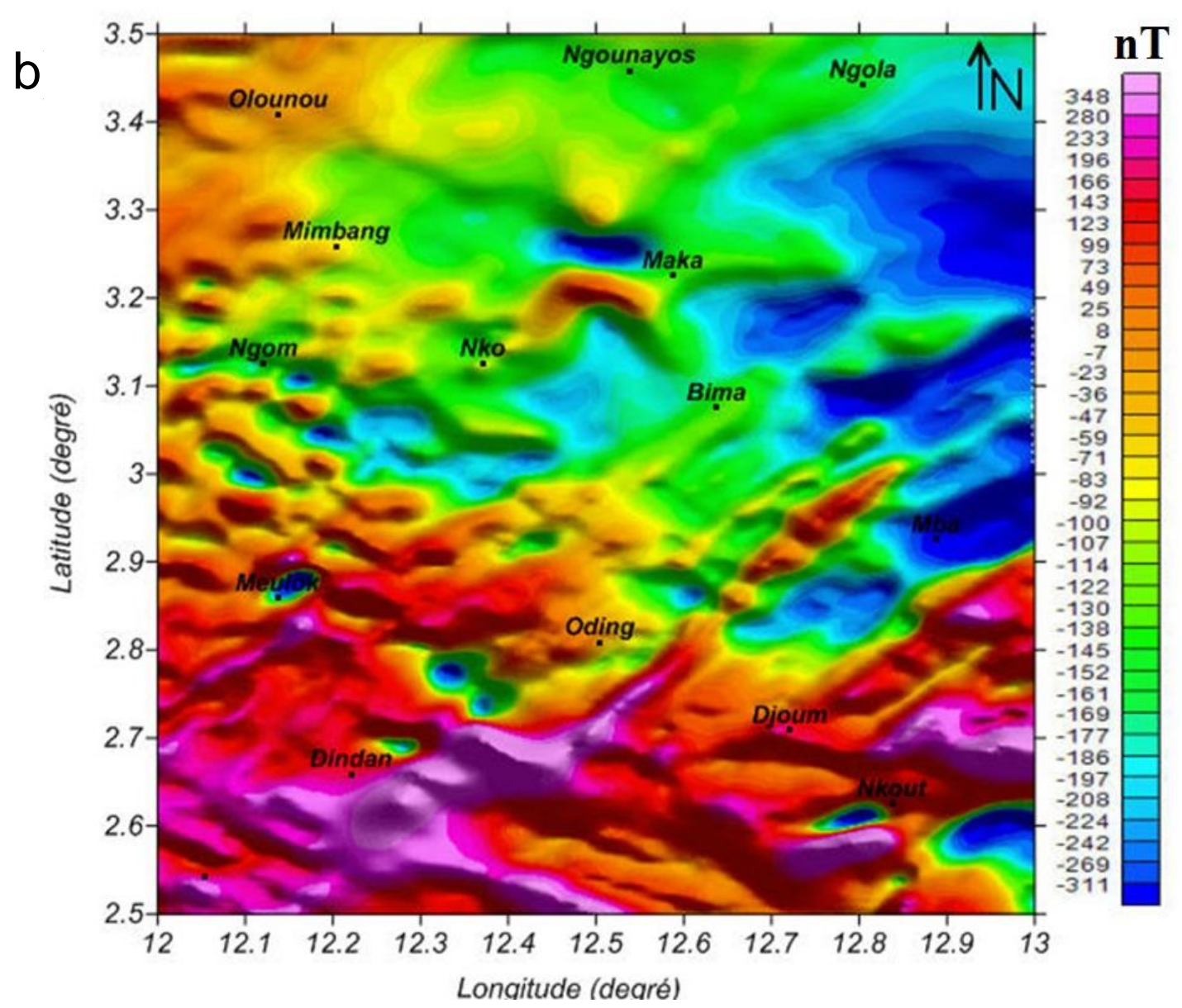

Figure 2. a) TMI of the study area; b) RTE of TMI

\subsubsection{Gravity Data}

The EGM (Earth Gravitational Model) 2008 data, publicly released by the National Geospatial-Intelligence Agency (NGA), were used in this study. This model includes a compilation of airborne gravity, terrestrial, and altimetry-derived data of 5 arc-minute spatial resolution (Palvis et al., 2008). The topographic effect and Bouguer correction were achieved using the 1 arc-minute by 1 arc-minute ETOPO1 elevation data, and a density of $2670 \mathrm{~kg} / \mathrm{m}^{3}$ respectively (Amante \& Eakins, 2008). EGM 2008 data effectively deal with the sparseness of land gravity or airborne data in some areas (Abate Essi et al., 2017) by providing a synoptic overview of the Earth.

The Bouguer gravity data (2,5 arc-minute by 2,5 arc-minute) used in this study were computed at IGB (International Gravimetric Bureau) from the EGM 2008 (Pavlis et al., 2008) via the FA2BOUG code (Fullea et al., 2008). Hence, the Bouguer anomaly map (Figure 3a) was derived the interpolation of 577 values.

The Interactive Spectrum Filtering (Band-pass Filtering of the power spectrum) was applied to Bouguer gravity data to dissociate shallow (residual) anomalies from deep (regional) ones. This was performed using Geosoft software v8.4. Hence, a short wavelength cutoff of $5420 \mathrm{~m}$ coupled with a long wavelength cutoff of $111000 \mathrm{~m}$ were achieved from the original grid. This allows us to display the residual grid (Figure $\mathbf{3 b}$ ). 

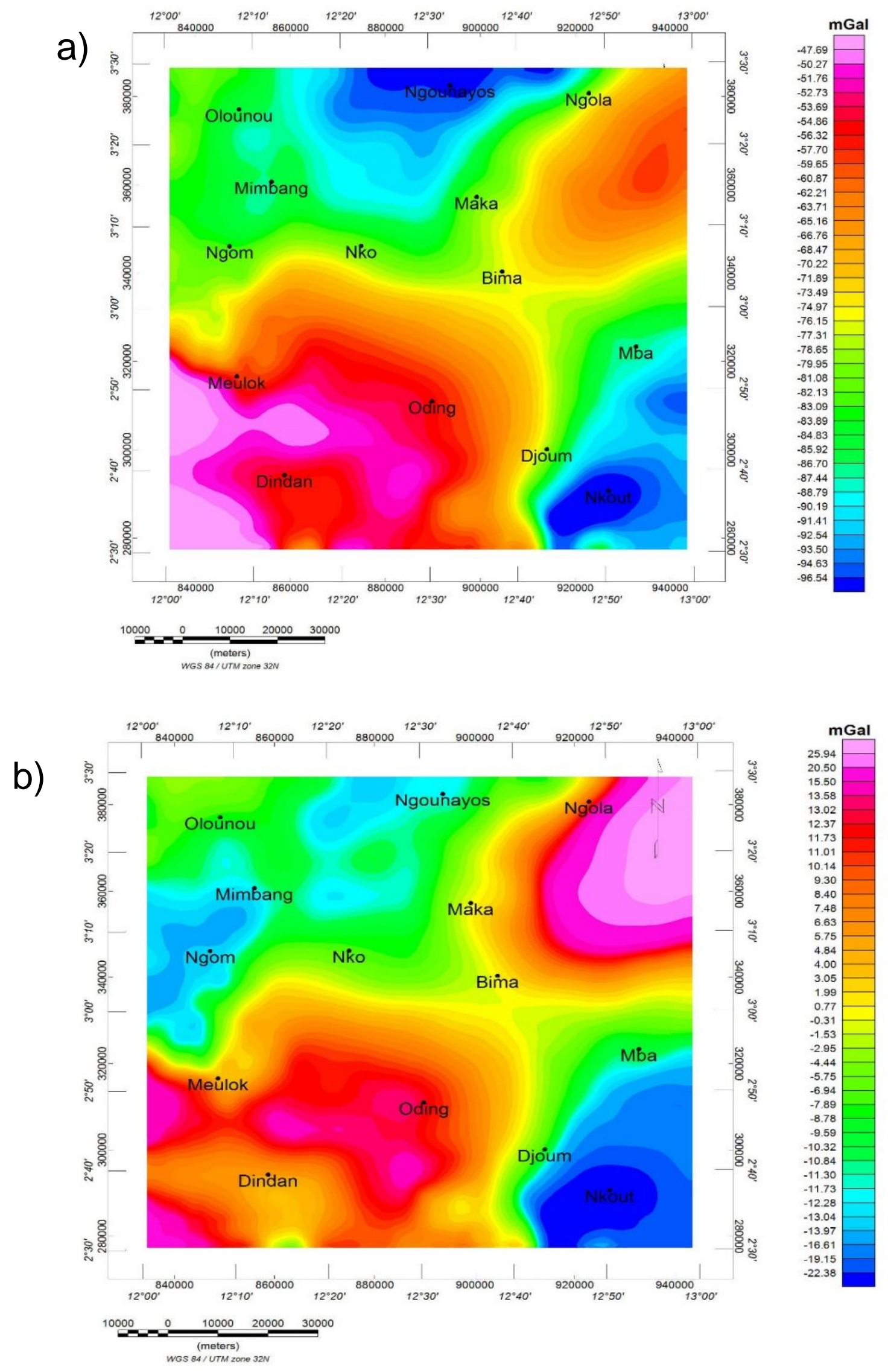

Figure 3. a) Bouguer anomaly map of the study area; b) residual anomaly map 


\subsection{Methods}

The extraction of magnetic lineaments of the study area was performed using two complementary approaches. The first approach involved the Horizontal Gradient method (HG), applied on the RTE grid (Figure 2b) to illustrate the locations of magnetic contacts associated with structural discontinuities. The second method was about gridding HG peak anomalies from which lineaments were traced.

On the other hand, gravity lineaments were enhanced from the residual anomaly grid (Figure 3b) through the application of the total horizontal derivative of the tilt derivative (TDR_THDR). Later on, CET Grid Analysis operator was subsequently used for lineaments extraction.

\subsubsection{The Horizontal Gradient (HG)}

The Horizontal gradient method is one of the commonly used methods to locate the edges of magnetic susceptibility sources. If $\mathrm{M}$ is the magnetic field then the horizontal gradient magnitude (HGM) is given by:

$$
H G M(x, y)=\overline{\left.\frac{\delta M}{(\delta x}\right)^{2}+\left(\frac{\delta M}{\delta y}\right)^{2}}
$$

This function gives a peak anomaly above magnetic contacts under the following assumptions: (1) the magnetizations are vertical, (2) the regional magnetic field is vertical, (3) the contacts are isolated, (4) the contacts are vertical and (5) the sources are thick; ignoring the first four assumptions can lead to shifts of the peaks away from the contacts; violations of the last assumption can lead to secondary peaks parallel to the contacts (Phillips 1998). In a view to partially satisfying the first two assumptions, it is usually required to perform a usual shift operation (Reduction-to-Equator) on the magnetic field.

Later on, the peak anomalies of the Horizontal Gradient grid were regridded based on Blakely \& Simpson (1986) method. That processing allowed us to delineate the targeted subsurface lineaments.

\subsubsection{The Total Horizontal Derivative of the Tilt Derivative (TDR_THDR)}

The TDR_THDR is a high pass filter, very effective in the mapping of mineral exploration targets such as shallow geologic edges (Geosoft's user guide, 2015). Moreover, since the depth of the upper end of causative sources (contacts) is inversely related to the gradient of the TDR_THDR, a grid threshold value can be used as a restricted depth discriminator that will enhance shallow sources (Verduzco et al., 2004).

The TDR_THDR equation (Verduzco et al., 2004) is expressed as follows:

$$
T D R_{-} T H D R=\sqrt{\left(\frac{\delta T D R}{\delta x}\right)^{2}+\left(\frac{\delta T D R}{\delta y}\right)^{2}}
$$

Where $\delta T D R / \delta x$ and $\delta T D R / \delta y$ are the first derivatives of the Tilt derivative (TDR) in the $\mathrm{x}$ and $\mathrm{y}$ directions.

$$
T D R=\tan ^{-1}\left(\frac{\delta f / \delta z}{\sqrt{(\delta f / \delta x)^{2}+\left(\delta f /(\delta y)^{2}\right.}}\right)
$$

Where $\mathrm{f}$ is the gravity field; $\delta \mathrm{f} / \delta x, \delta f / \delta y$ and $\delta f / \delta z$ are the first derivatives of the field in the $\mathrm{x}, \mathrm{y}$, and $\mathrm{z}$ directions respectively.

For gravity lineaments extraction, the TDR_THDR grid was used as input for CET Grid Analysis.

\subsubsection{CET Grid Analysis Algorithm}

This operator was developed at the Centre for Exploration Targeting (CET) in Australia by Holden et al., (2012). It is suitable for texture analysis, lineation vectorization, lineation detection, and structural complexity. Indeed, this technique allows the measurement of the textural information within a well-set windows in a database and the statistical randomness of neighbouring data values as well (Rustami et al., 2017). In other words, this tool allows the extraction of lineaments from a potential signal. The 4-step processes of the operator used in this study include: congruency robustness, amplitude thresholding, skeletonisation, and vectorization.

\section{Results}

\subsection{Horizontal Gradient}

To delineate the position of magnetic contacts at depth, the processing was carried out by the application of the 
horizontal gradient operator to the RTE grid as shown in Figure 4a. This map displays magnetic contacts maxima over the magnetic sources.

The horizontal gradient map shows highly graded linear anomalies suggesting high magnetic susceptibility bodies in the southern part, which may be related to igneous and metaigneous rocks rich in ilmenite and magnetite (Ntem Complex); those linear signatures mostly trend in the ENE-WSW and NE-SW directions. On the other hand, less-graded anomalies mainly affecting the northern part in the E-W direction suggest low magnetic susceptibility sources rich in felsic minerals (Yaounde Domain).

The directions identified on HG map correlate well with the ones highlighted by Ndougsa-Mbarga et al., (2012) and Feumoe et al., (2012) using the HG and the First Vertical Derivative respectively in the southeast (neighbouring the study area); the ENE-WSW and NE-SW always being predominant.

In order to extract magnetic lineaments, the maxima of the horizontal gradient map was realized (Figure $\mathbf{4 b}$ ). Those peaks were gridded by applying a threshold value of $2000 \mathrm{nT} / \mathrm{km}$. From this level, we have been able to trace out the magnetic lineaments of the area (Figure 4c) using ArcGis 10.4.1 software. The rose diagrams in Figure 4c show the statistical length (left rose diagram) and distribution (right rose diagram) of the main lineaments orientations occurring within the study area. The rose diagrams highlight the predominance of NE-SW to ENE-WSW trends in both length and frequency.

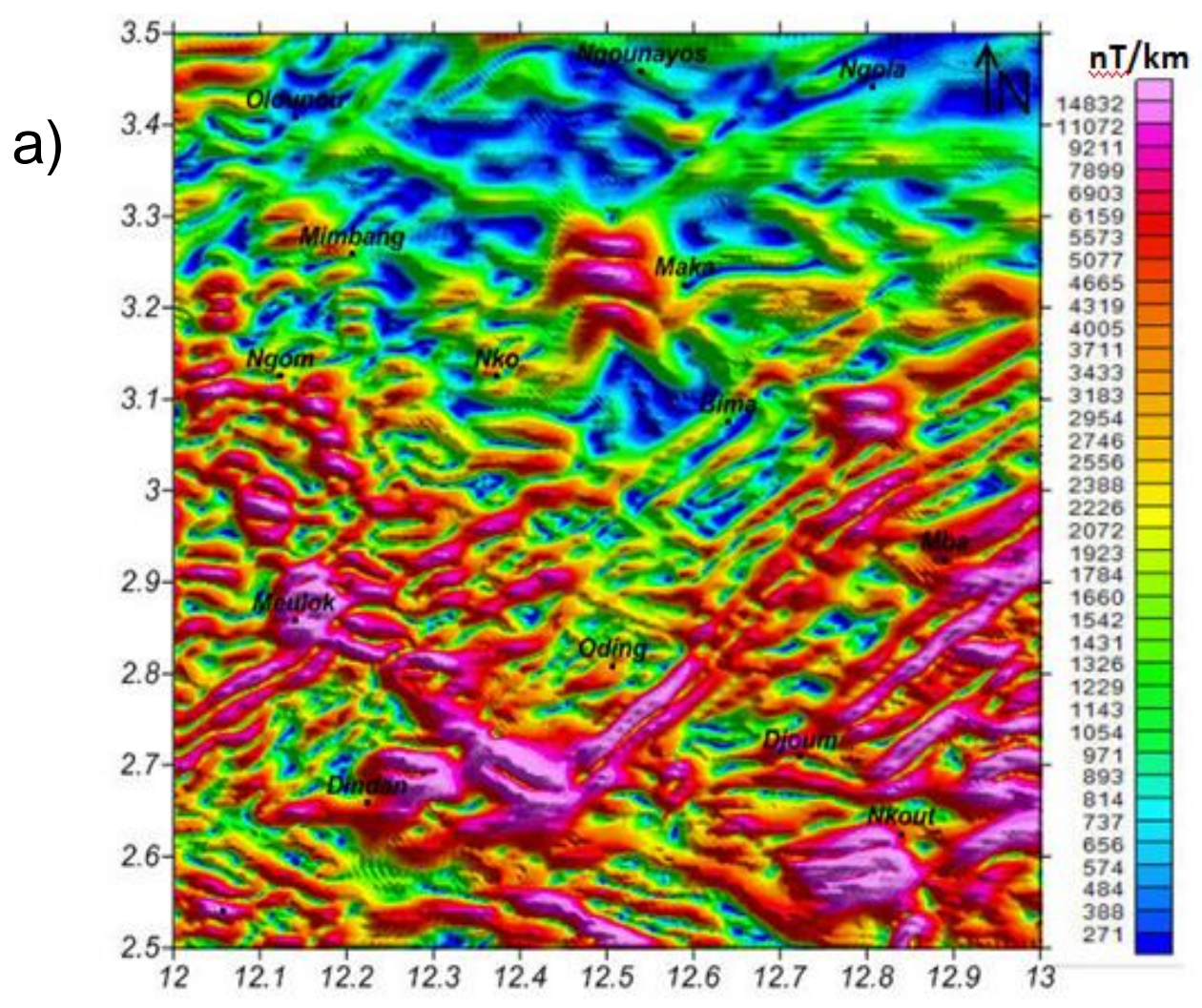


b)

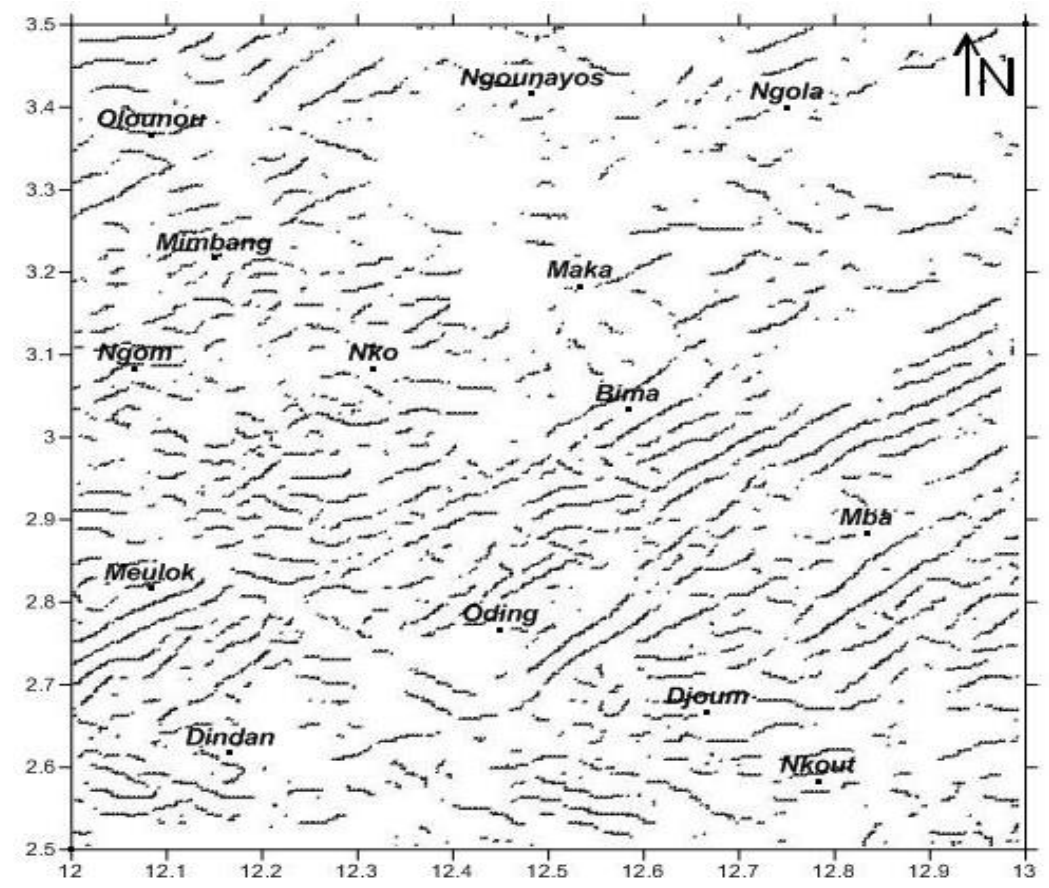

c)

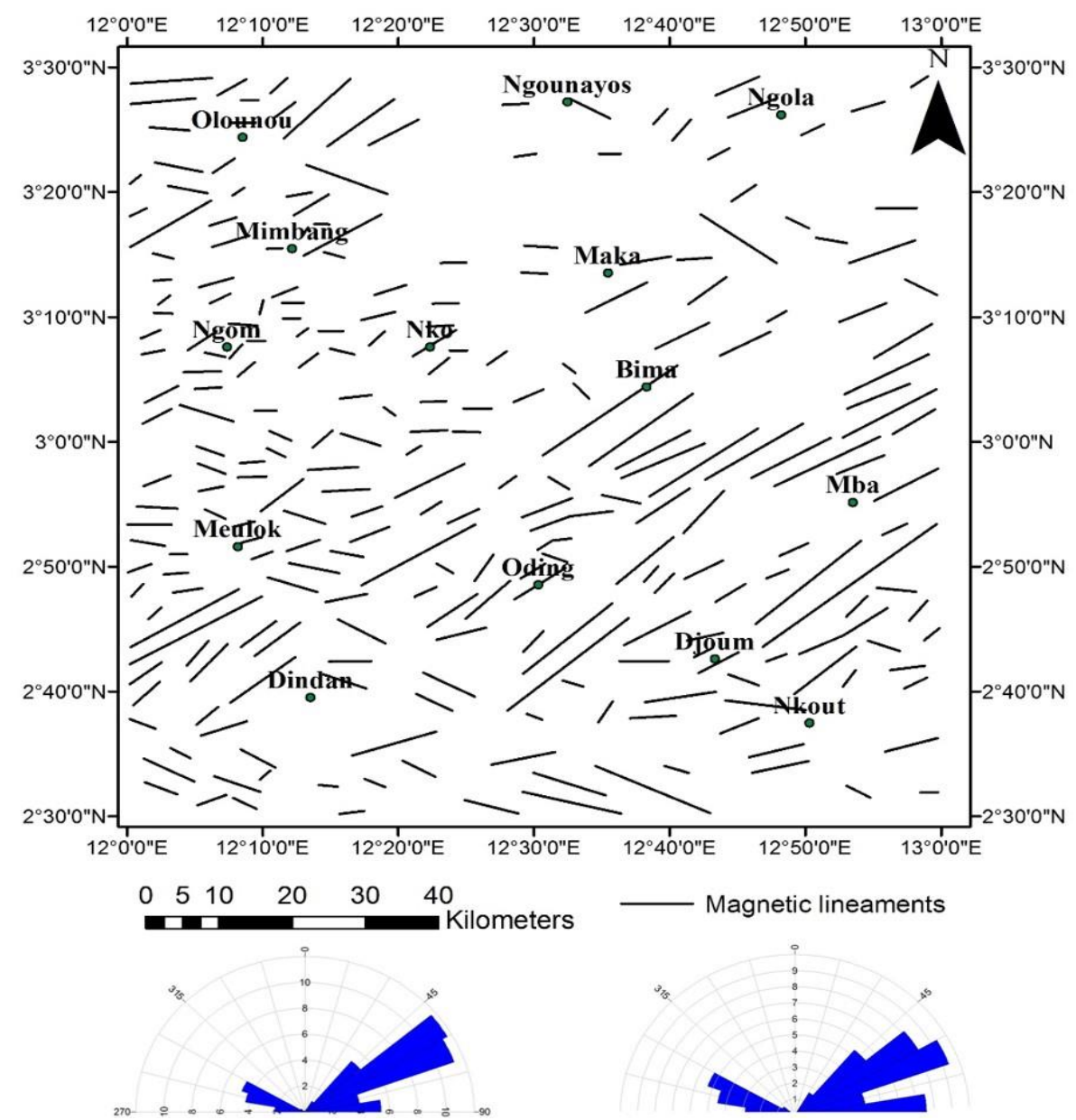

Figure 4. a) Horizontal gradient of the RTE map; b) Maxima of the Horizontal gradient of the RTE; c) magnetic lineaments map of the study area 


\subsection{The Total Horizontal Derivative of the Tilt Derivative (TDR_THDR)}

The TDR_THDR map (Figure 5) was obtained from the TDR of the residual of the Bouguer anomaly. The amplitude of the TDR_THDR ranges from 0.00002 to over $0.00039 \mathrm{Rad} / \mathrm{m}$. Color-shaded was applied on the TDR_THDR grid in a view to enhancing the effect of the structural pattern affecting the area. Narrow linear/circular short-wavelength (shallow) structures trending E-W (subhorizontal) and N-S (subvertical) can be observed. High positive values of structures extend from the southern part to the western border, suggesting high-density materials, which could be related to the charnockitic suite. Hence, this could be of high interest for ongoing or prospective mineral exploration carried out in the area.

During the process of lineaments extraction from the TDR_THDR grid, an amplitude thresholding (second step process) value of $0.00006 \mathrm{Rad} / \mathrm{m}$ was applied to the CET Grid Analysis operator before skeletonization and vectorization. This allowed us to obtain automatically extracted structures of interest, which were overlaid on the TDR_THDR grid as shown in Figure 5.

As a result, 127 gravity structures were delineated. The rose diagrams show the statistical length (left rose diagram) and distribution (right rose diagram) of the lineaments. Hence, the major lineament directions are N-S and E-W; the longer lineaments being the E-W ones. Lineaments 1, 2, 3, 4, and 5, when merged, may correspond to a portion of the suture zone separating the YD from the NC, as described by Maurizot et al., (1986). However, the extracted suture zone seems to be slightly shifted to the south when compared to well-known suture zone.

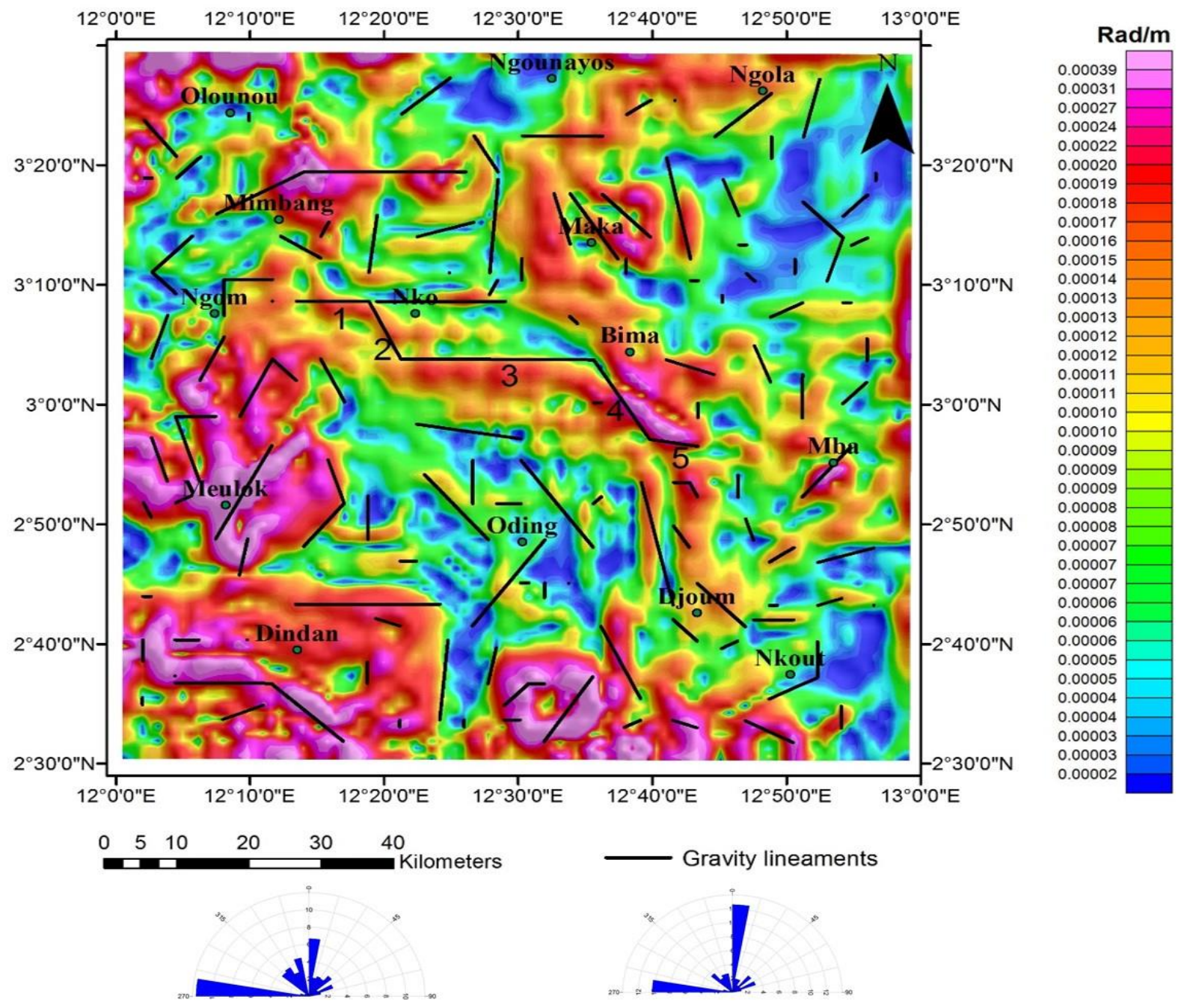

Figure 5. Color shaded THDR_TDR map with extracted gravity lineaments superimposed 


\subsection{Lineament Map of the Area}

The superimposition of both magnetic and gravity lineaments enabled us to obtain the lineament map of the study area (Figure 6).

The rose diagram on the left shows the statistical length of trending directions while the rose diagram on the right illustrates the major directions. Hence, the main directions are E-W, ENE-WSW, and NE-SW. The longest structures belong to the NE-SW and ENE-WSW trending directions and they are more concentrated in the southern part of the area.

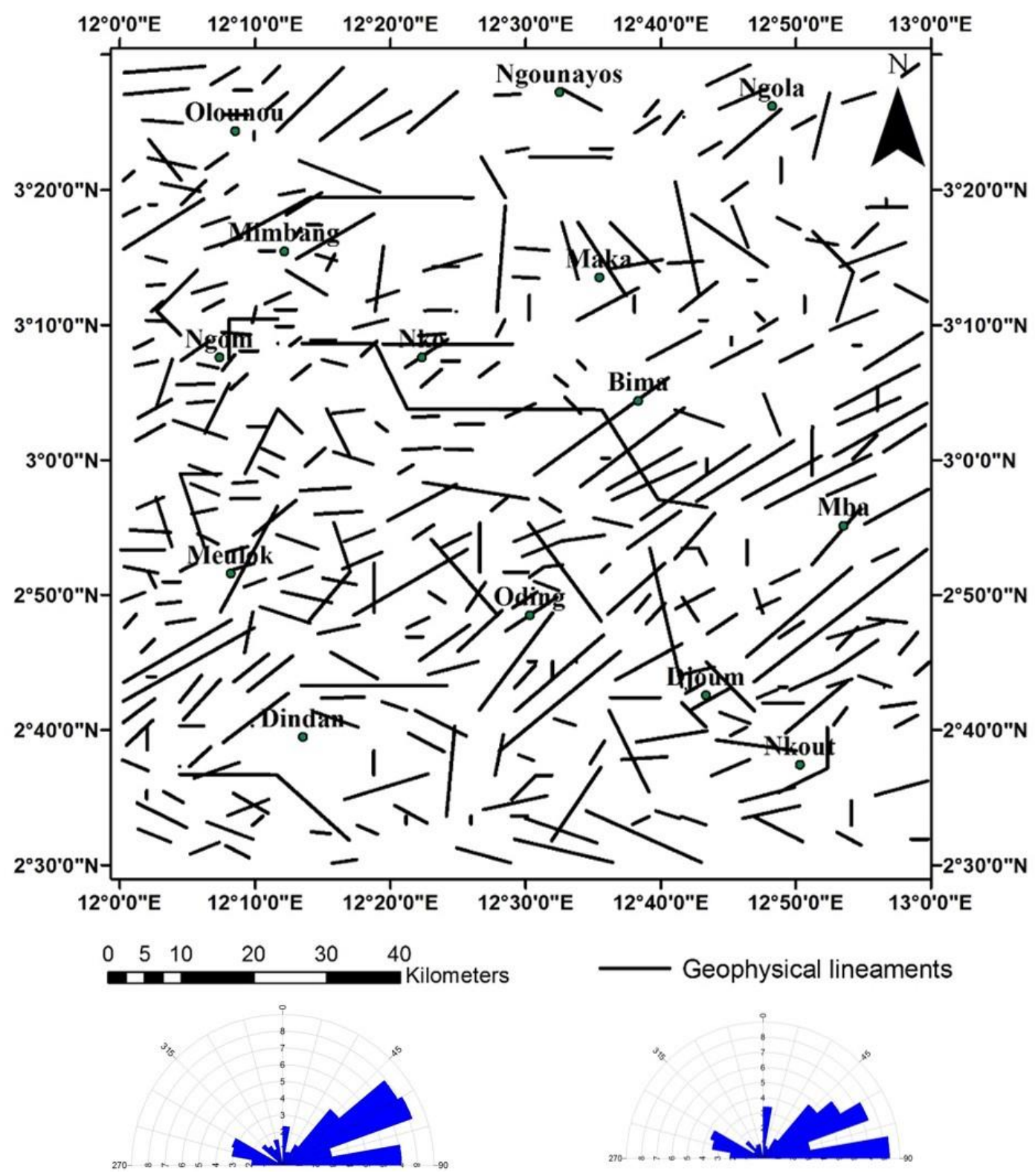

Figure 6. Structural map of the study area

\section{Discussion}

\subsection{Lineament Map of the Area}

According to the structural framework displayed in Figure 6, the study area can be divided into two domains: the Northern area, highly dominated by multiple lineaments directions and the Southern area mostly shaped by a single structural direction.

In the Northern area, around Ngounayos, Ngola, Maka, Mimbang, Olounou, Bima and Nko, we notice 
heterogeneity in the structural trends and distribution of the magnetic lineaments. Indeed, these diverse orientations including E-W, NE-SW, and NW-SE, appear to cover the YD.

- The NE-SW to ENE-WSW trends found within the YD (Pan-African mobile belt) could be linked to the Central African Shear Zone (CASZ), which is a dextral shear zone that extends some $2000 \mathrm{~km}$ in west Cameroon to Sudan. (Ngako et al., 2003). However, by considering the subduction context (overthrusting of Pan-African onto Congo craton) of the study area, these directions could be related to a post-Pan-African tectonic event having simultaneously affected the two entities or may represent hidden structures covered by the Pan-African units. This last hypothetical statement suggests a deep-seated extension of the Congo craton structures to the North, enhanced by aeromagnetic data processing. Indeed, geophysical studies from Boukeke (1994), Tadjou et al., (2004), Shandini et al., (2010), Basseka et al., (2011), Ndougsa-Mbarga et al., (2014) suggested the northern limit of the Congo craton to be approximately $4^{\circ} \mathrm{N}$.

- The E-W trends correlate well with the regional direction of the Oubanguide complex which extends from western Cameroon to the East of Central African Republic (Toteu et al., 2006) and therefore could be linked to the Pan-African orogeny. However, according to Boukeke (1994), the E-W direction is characteristic of the basement complex. Hence, the occurrence of the E-W trending faults in the Northern area (Pan-African) may represent the signature of deep-seated structures affecting the basement, thereby confirming the subduction event between the two major entities of the study area.

- The NW-SE to WNW-ESE trend is more present in the Pan-African domain. This direction is in perfect accordance with those found by Basseka et al., (2011) based on gravity data. This suggests a tectonic event related to the Pan-African orogeny or to a post-Pan-African time (<550-600 Ma).

In the southern area, around Nkout, Djoum, Oding, Dindan, Meulok, Ngom and Mba, the magnetic lineaments are much longer than the ones found in the northern domain. The major trending directions vary from NE-SW to ENE-WSW. These trends appear to cover the NC. Besides, these directions, known to be the characteristic trends of the Congo craton, are in accordance with the ones found by Shandini et al., (2011) and Basseka et al,. (2011) based on gravity data processing. The ENE-WSW and NE-SW trends observed by Shandini et al., (2011) were delineated up to a depth of $10 \mathrm{~km}$ via gravity data enhancement. Moreover, Ndougsa-Mbarga et al., (2012) identified the same trends in the southeast region, up to $1500 \mathrm{~m}$ deep, based on aeromagnetic data enhancement.

- The NE-SW directions found here may be linked to the Eburnean orogeny (2400-1800 Ma), which is associated with the collision of the Congo and Sao Francisco cratons, remobilizing the western part of the Ntem Complex into the Nyong Complex. (Penaye et al., 2004; Owona et al., 2013).

- The ENE-WSW trend is well known to be the subduction direction of the Pan-African mobile belt onto the Congo craton (Ndougsa-Mbarga et al., 2012; Owona Angue et al., 2013). Besides, this direction is commonly found on the basement complex and may suggest a tectonic event prior to Pan-African orogeny.

\subsection{Correlation of Results With Known Iron ore Prospects and TMI Map of Djoum}

The iron ore prospect map (Figure 7a) of Nkout locality (southeast of the study area) illustrates a major regional ENE-WSW to E-W trend along which iron ore deposits have been formed. This direction correlates well with those described by the structural map (Figure 6). Hence, by considering the potential mineralizations of the area, the lineaments found in this study may be considered as great targets for prospective mineral exploration.

The Nkout Iron prospect is situated in the Company's Djoum licence in the western part of South Cameroon. The TMI map of Djoum exploration license (Figure 7b), obtained from the International Mining \& Infrastructure Corporation (IMIC), shows NE-SW to ENE-WSW, E-W and NW-SW to WNW-ESW trending structures, which are in accordance with the major trending directions found in this study, as illustrated on the rose diagrams (Figure 6). This suggests that more attention must be paid to anomalies with high gradients in the context of prospective iron ores exploration undertaken within the study area. 


\section{$12 \mathrm{~km}$ strike drill tested to date at Nkout}

a)

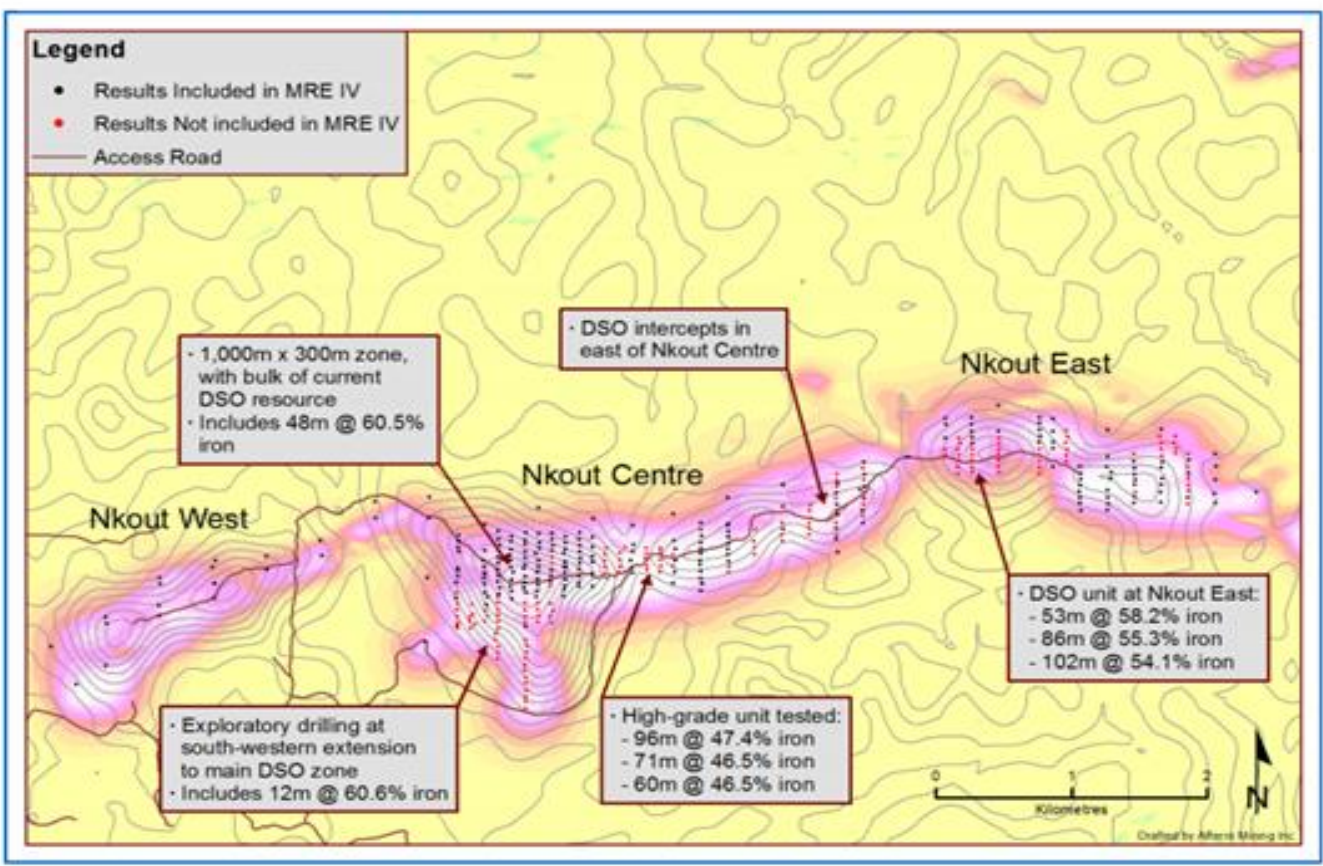

b)

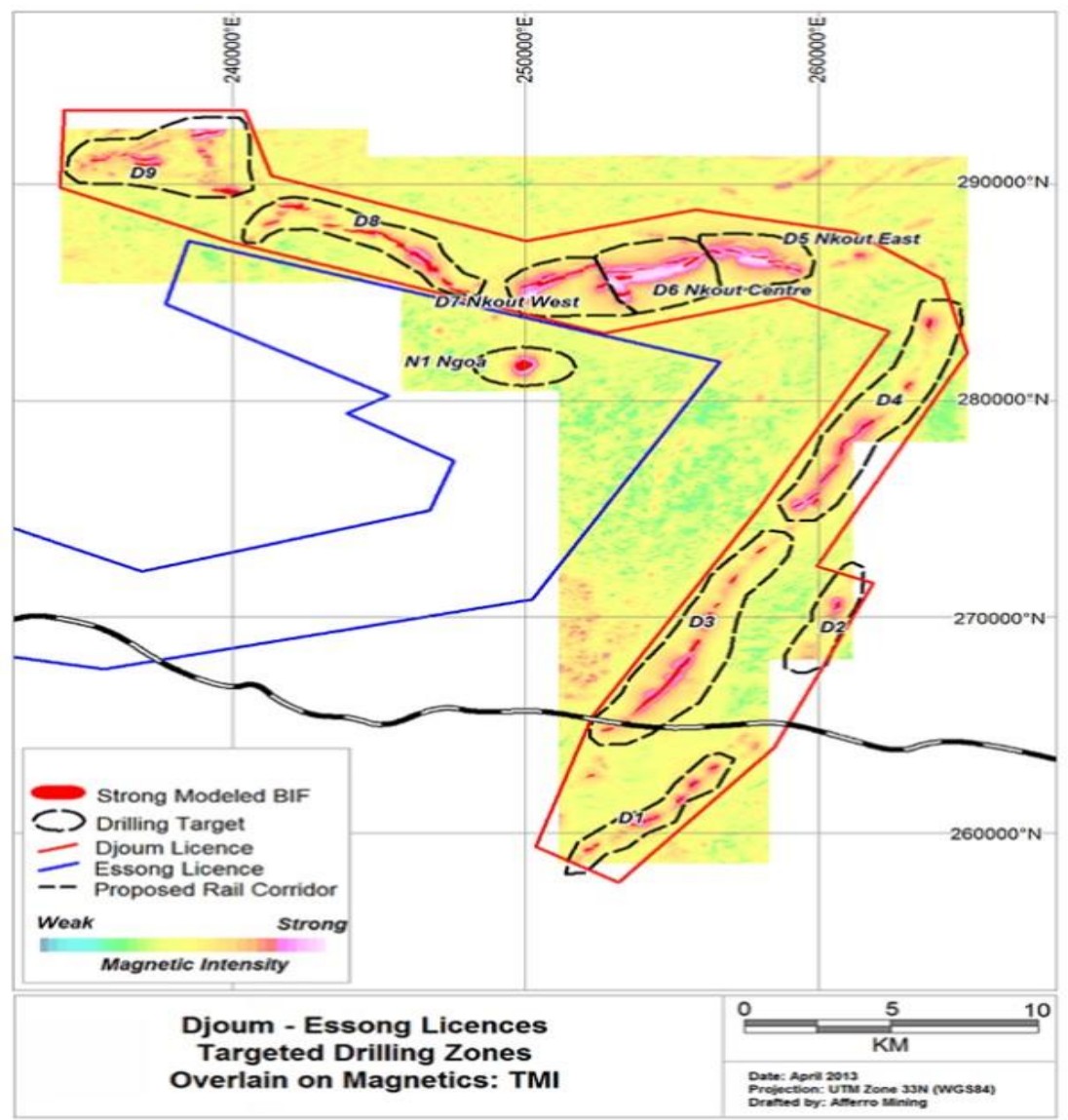

Figure 7. a) Iron ore prospects map of Nkout locality; b) Magnetic intensity map of the Djoum exploration license (source: http://www.imicplc.com/Nkout.aspx) 


\section{Conclusion}

The aim of this work was to provide a new insight into the subsurface structural network of the western portion of South Cameroon. The enhancement of both aeromagnetic and EGM 2008 data allowed the discrimination of lineaments. The major lineaments trends are E-W, ENE-WSW, and NE-SW. These lineaments directions are in perfect accordance with former studies based on gravity and aeromagnetic data analysis. The context of subduction event between the Congo craton and the Pan-African mobile belt suggests a buried extension of the Congo craton structures to the North. Indeed, Boukeke (1994), Tadjou et al., (2004) suggested that the northern limit of the Congo craton could be approximately $4^{\circ} \mathrm{N}$. Hence, NE-SW to ENE-WSW and E-W trending faults enhanced in this work may represent hidden Archean faults related to an early event (Liberian orogeny). Besides the NE-SW direction may also be related to the Eburnean orogeny linked to the collision between Congo and Sao Francisco cratons. Thereby considering that the Congo craton has been affected by Liberian, Eburnean and Pan-African orogenies (Tchameni et al., 2001; Penaye et al., 2004), it should be perceived that these faults directions are also connected to the CASZ (Ndougsa-Mbarga et al., 2012; Owona Angue et al., 2013). Furthermore, the study area encompasses localities which are known as the richest iron ore deposits areas in Cameroon (Nkout, Djoum). Thus, the structural map obtained from this study could constitute a great reliable tool for further mineral exploration within the area and prospective mineral provinces. This is illustrated by the good correlation between trending directions found here and iron prospects of Nkout locality.

\section{Acknowledgements}

The authors are grateful to GETECH Group plc and the National Geospatial-Intelligence Agency (NGA), for providing the data used in this study.

\section{References}

Abate, E. J. M., Yene, A. J. Q., Ahmad, A. D., Dassou, E. F., Mbossi, E. F., Ondoa, J. M., \& Penaye, J. (2017). Interpretation of gravity data derived from the Earth Gravitational Model EGM2008 in the CenterNorth Cameroon: structural and mining implications. Arab Journal of Geosciences, 10(130). https://doi.org/10.1007/s12517-017-2919-y

Abdelsalam, G. M., Liégeois, L., \& Stern, R. J. (2002). The Saharan Metacraton. Journal of African Earth Sciences, 34, 119-136.

Amante, C., \& Eakins, B. W. (2008). ETOPO1 1 Arc-Minute Global Relief Model: Procedures, Data Sources and Analysis. National Geophysical Data Center, NESDIS, NOAA, U.S. Department of Commerce, Boulder, CO.

Basseka, C. A., Njiteu, C. D., Eyike, Y. A., Shandini, Y., \& Kenfack, J. V. (2016). Apport des données magnétiques de surface et satellitaires à l'étude des structures profondes du Sud Cameroun. Sciences, Technologies et Développement, 18, 15-30.

Basseka, C. A., Shandini, Y. N., \& Tadjou, J. M. (2011). Subsurface Structural Mapping Using Gravity Data of the northern edge of the Congo Craton, South Cameroon. Geofizika, 28(2), 231-244.

Blakely, R. J., \& Simpson, R. W. (1986). Approximating edges of source bodies from magnetic or gravity anomalies. Geophysics, 51(7), 1494-1498.

Boukeke, D. B. (1994). Structures crustales d'Afrique centrale déduites des anomalies gravimétriques et magnétiques: le domaine Précambrien de la République Centrafricaine et du sud Cameroun. ORSTM Editions, Paris, $N^{\circ} 126$.

Feumoe, S., Ndougsa-Mbarga, T., \& Manguelle-Dicoum. (2012). Delineation of tectonic lineaments using aeromagnetic data for the south-east Cameroon area. Geofizika, 29, 175-192.

Fullea, J., Fernandez, M., \& Zeyen, H. (2008). FA2BOUG - A FORTRAN 90 code to compute Bouguer gravity anomalies from gridded free-air anomalies: Application to the Atlantic-Mediterranean transition zone. $\begin{array}{llll}\text { Computers } \& \text { Geosciences, } & \text { 34(12), 1665-1681. ISSN:0098-3004. }\end{array}$ http://doi.org/10.1016/j.cageo.2008.02.018.

Geosoft (Oasis Montaj) Program, Geosoft Mapping and Application System. (2015). Inc, Suit 500, Richmond St. West Toronto, ON Canada N5SIV6. Users' Manual.

Holden, E. J., Wong, J. C., Kovesi, P., Wedge, D., \& Dentith, M. (2012). Identifying regions of structural complexity in regional aeromagnetic data for gold exploration: An image analysis approach. Ore Geology Reviews, 46, 47-59. 
Maurizot, P., Abessolo, A., Feybesse, A., Johan, J. L., \& Lecompte, P. (1986). Etude et prospection minière au Sud-Ouest Cameroun. Synthèse des travaux de 1978-1985. Rap. BRGM 85 CNRS 066, Orléans, 274p.

Ndougsa-Mbarga, T., Feumoé, A. N. S., Manguelle-Dicoum, E., \& Fairhead, J. D. (2012). Aeromagnetic Data Interpretation to Locate Buried Faults in South-East Cameroon. Geophysica, 47, 1-2, 49-63.

Ndougsa-Mbarga, T., Yufenyiu, L. D., Yene-Atangana, J. Q., \& Tabod, T. C. (2014). Delineation of the northern limit of the Congo Craton based on spectral analysis and 2.5D modeling of aeromagnetic data in the Akonolinga-Mbama area, Cameroon. Geofisica internacional, 53(1), 5-16.

Nédélec, A., Nsifa, E. N., \& Martin, H. (1990). Major and trace element geochemistry of the Archaean Ntem plutonic complex South Cameroon: petrogenesis and crustal evolution. Precambrian Research, 47, 35-50.

Nforba, M. T., Suh, C. E., \& Kabeyene, K. V. K. (2010). Mbalam iron ore project, northern edge of the Congo craton, southeast Cameroon. SEG Extended Abstracts, Colorado G-22.

Ngako, V., Affaton, P., Nnange, J. M., \& Njanko, T. (2003). Pan-African tectonic evolution in central and southern Cameroon: transpression and transtension during sinistral shear movements. Journal of African Earth Sciences, 36(3), 207-214.

Nzenti, J. P., Barbey, P., Macaudière, J., \& Soba, D. (1988). Origin and evolution of the late Precambrian high-grade Yaoundé gneisses (Cameroon). Precambrian Research, 38, 91-109.

Owona, A. M. L. C., Tabod, T. C., \& Nguiya, S. (2013). Delineation of Lineaments in South Cameroon (Central Africa) Using Gravity Data. Open Journal of Geology, 3, 331-339.

Owona, S. M., Ndzana, S. P., \& Mvondo, O. J. (2012). Geological control of geomorphologic units in the Southwest (SW) Cameroon (Central Africa). Journal of Geology and Mining Research, 4(7), 152-167.

Owona, S., Mbola-Ndzana, S. P., Mpesse, J. E., Mvondo-Ondoa, J., Schulz, B., Pfänder, J., .. \& Kodeck, G. E. (2013). Petrogenesis of amphibolites from the Neoproterozoic Yaounde Group (Cameroon, Central Africa): Evidence of MORB and implications on their geodynamic evolution. Comunicações Geológicas, 100(1), 5-13.

Palvis, N. K., Holmes, S. A., Kenyon, S. C., \& Factor, J. K. (2008). An Earth Gravitational Model to degree 2160: EGM 2008. Presented at the EGU General Assembly, Vienna, Austria, April 13-18.

Penaye, J., Toteu, S. F., Tchameni, R., Van Schmus, W. R., Tchakounté, J., Ganwa, A., \& Nsifa, E. N. (2004). The 2.1 Ma West Central African Belt in Cameroon: extension and evolution. Journal of African Earth Sciences, 39, 159-164.

Phillips, J. D. (1998). Processing and Interpretation of Aeromagnetic Data for the Santa Cruz Basin - Patahonia Mountains Area, South-Central Arizona. U.S. Geological Survey Open-File Report, Arizona, 02-98.

Poidevin, J. L. (1983). La tectonique Pan-Africaine à la bordure nord du craton congolais: l'orogenèse des Oubanguides, in Colloque on the African geology, 12, Musée Royal de l'Afrique Centrale, Tervuren, Belgium, Abstract, 75 .

Pouclet, A., Tchameni, R., Mezger, K., Vidal, M., Nsifa, N. E., \& Penaye, P. (2007). Archaean crustal accretion at the northern border of the Congo Craton (South Cameroon). The charnockite-TTG link. Bull. Soc. Geol. Fr., 178(5), 3-14.

Rustami, S., Saadi, N. M., Aboud, E., Yonezu, K., \& Watanabe, K. (2017). Investigating Structural and Tectonic Evolution of Central Afghanistan Using Remote Sensing and Gravity Data. J Geol Geophys, 6, 313. http://doi.org/10.4172/2381-8719.1000313.

Shandini, N. Y., Tadjou, J. M., \& Basseka, C. A. (2011). Delineating deep basement faults in South Cameroon area, World Appl. Sci. J., 14, 611-615.

Shandini, N. Y., Tadjou, J. M., Tabod, C. T., \& Fairhead, J. D. (2010). Gravity data interpretation in the northern edge of the Congo Craton, South-Cameroon. Anuario do Instituto de Geociências, 33(1), 73-82.

Shang, C. K., Satir, M., \& Siebel, W. (2004). TTG magmatism in the Congo craton; a view from major and trace element geochemistry, $\mathrm{Rb}-\mathrm{Sr}$ and $\mathrm{Sm}-\mathrm{Nd}$ systematic: case of Sangmelima region, Ntem complex, southern Cameroon. Journal of African Earth Sciences, 40, 61-79.

Shang, C. K., Satir, M., Nsifa, E. N., Liegeois, J. P., Siebel, W., \& Taubald, H. (2007). Archaean highK granitoids produced by remelting of the earlier Tonalite-Trondhjemite-Granodiorite (TTG) in the Sangmelima region of the Ntem complex of the Congo craton, southern Cameroon. Int. J. Earth Sci., 96, 
817-842.

Tadjou, J. M., Manguelle-Dicoum, E., Tabod, C. T., Nouayou, R., Kamguia, J., Njandjock, N. P., \& Ndougsa, M. T. (2004). Gravity modelling along the northern margin of the Congo Craton, south-Cameroon, J. Cameroon Acad. Sci, 4, 51-60.

Tadjou, J. M., Nouayou, R., Kamguia, J., Kande, H. L., \& Manguelle-Dicoum, E. (2009). Gravity analysis of the boundary between the Congo craton and the Pan-African belt of Cameroon. Austrian J. EarthSci., 102, 71-79.

Takam, T., Arima, M., Kokonyangi, J., Dunkley, D. J., \& Nsifa, E. N. (2009). Paleoarchaean charnockites in the Ntem complex, Congo craton, Cameroon: insights from SHRIMP zircon U-Pb ages. J. Mineral. Petrol. Sci. 104, 1-11.

Tchameni, R. (1997). Géochimie et géochronologie des formations de l'Archéen et du Paléoproterozoïque du Sud-Cameroun (Groupe du Ntem, Craton du Congo). Thèse de l'Univérsité d'Orléans, France (395p).

Tchameni, R., Lerouge, C., Penaye, J., Cocherie, A., Milesi, J. P., Toteu, S. F., \& Nsifa, E. N. (2010). Mineralogical constraint for metamorphic conditions in a shear zone affecting the Archean Ngoulemakong tonalite, Congo craton (southern Cameroon) and retentivity of U-Pb SHRIMP zircon dates. J. Afr. Earth Sci. 58, 67-80.

Tchameni, R., Mezger, K., Nsifa, E. N., \& Pouclet, A. (2001). Crustal origin of early Proterozoic syenites in the Congo craton (Ntem complex), South Cameroon. Lithos, 57, 23-42.

Tchameni, R., Pouclet, A., Mezger, K., Nsifa, E. N., \& Vicat, J. P. (2004). Monozircon and Sm-Ndwhole rock ages from the Ebolowa greenstone belts: evidence for the terranes older than $2.9 \mathrm{Ga}$ in the Ntem complex (Congo craton, South Cameroon). J. Cameroon Acad. Sci, 4(3), 213-224.

Tessontsap, T., Tomaso, R. R. B., Paul-Désiré, N., Johannes, C. V., Damon, T., Matthew, C., \& Derek, V. (2017). Petrography and geochemistry of the Mesoarchean Bikoula banded iron formation in the Ntem complex (Congo craton), Southern Cameroon: Implications for its origin. Ore Geology Reviews, 80, $267-288$. http://dx.doi.org/10.1016/j.oregeorev.2016.07.003

Toteu, S. F., Penaye, J., \& Poudjom, D. Y. (2004). Geodynamic evolution of the Pan-African belt in central Africa with special reference to Cameroon. Can. J. Earth Sci., 41, 73-85.

Toteu, S. F., Van Schmus, R. W., Penaye, J., \& Michard, A. (2001). New U-Pb and Sm-Nd data from north-central Cameroon and its bearing on the pre-Pan-African history of central Africa. Precambrian Research, 108, 45-73.

Toteu, S. F., Van Schmus, W. R., Penaye, J., \& Nyobe, J. B. (1994). U-Pb and Sm-Nd evidence for eburnean and pan-African high grade metamorphism in cratonic rocks of southernCameroon. Precambrian Res., 67, 321-347.

Toteu, S. F., Yongue, F. R., Penaye, J., Tchakounté, J., Seme, M. A. C., VanSchmus, W. R., Deloule, E., \& Stendal, H. (2006). U-Pb dating of plutonic rocks involved in the nappe tectonic in southern Cameroon: consequence for the Pan-African orogenic evolution of the central African fold belt. J. Afr. Earth Sci., 44, 479-493.

Verduzco, B., Fairhead, J. D., Green, C. M., \& Mackenzie, C. (2004). New insights into magnetic derivatives for structural mapping, Lead. Edge, 23, 116-119.

Vicat, J. P. (1998). Esquisse géologique du Cameroun: in Géosciences au Cameroun. Collection GEOCAM, 1/1998, 3-11.

Yandjimain, J., Ndougsa-Mbarga, T., Bikoro, B. M., \& Meying A. (2018). Aeromagnetic Data Modeling for Geological and Structural Mappings over the DJADOM-ETA Area, in the Southeastern Cameroon. International Journal of Geosciences, 9, 354-370.

\section{Copyrights}

Copyright for this article is retained by the author(s), with first publication rights granted to the journal.

This is an open-access article distributed under the terms and conditions of the Creative Commons Attribution license (http://creativecommons.org/licenses/by/4.0/). 